\title{
The Cognitive comparative analysis of some verbs of motion in the Russian and English languages
}

\author{
Rita B. Kenetova - Alla V. Abregova - Aminat G. Khamurzova - Elmira R. \\ Khutova
}

\section{DOI: 10.18355/XL.2017.10.04.21}

\begin{abstract}
This paper reveals the cognitive status of polysemy as a linguistic phenomenon. An attempt is made to determine the range of semantic realizations of verbs of motion in the Russian and English languages. The paper discusses the verbs ekhat'-ezdit'/ to goto ride-to drive, idti-khodit' /to go-to walk in the cognitive-comparative aspect. The article examines the volume of meanings and the degree of coincidence/discrepancy of the given verbs in terms of the volume of meanings in both languages. We make an attempt to reveal the cognitive peculiarities of the verbs of motion in each of the studied languages. The idioethnic features of semantics and tropeization of the verbs of motion in the given languages against the background of the universal characteristics are identified.
\end{abstract}

Key words: verbs of motion, cognitive analysis, lexical-semantic group, epidigmatics, cognitive map of a word, volume of a word meaning, the specific and the universal

\section{Introduction}

The research of the human factor in the language, or language cognition, is becoming increasingly important. At the present time it has become commonplace to assert that the language role in the cognition of the world is extraordinarily great. "Native speakers of different languages can see the world in different ways, in the light of their own languages" (Apresyan, 1995). The language role is especially noticeable in the human perception of everything which surrounds us, when we compare two or more languages within the scope of a particular semantic system, within the semantic field, or semantic group which represents a semantic microfield. Against the background of the anthropomorphic universality of the general picture of the world the human vision of the world is surprisingly diverse, having a vivid manifestation in natural languages. It is shown at all levels of the language, but the specific against the background of the universal is more vividly shown at the lexical level, particularly, in the structure of the meaning of a polysemantic word. "Polysemy can be considered as one of the most vivid features of the national identity of the lexicon" (Fomina, 1990).

In recent decades both Russian and foreign scientists write about the connection between the semantic structures of polysemantic words as fragments of the language picture of the world and the language cognition - Shmelev (2006), Gak (2010), Solntsev (1971), Dibrova (1997), Fomina (1990), Cubryakova (2004), Zheltukhina et al. (2017a,b), Golubkova, Masalimova and Bírová (2017), Lyons (1978), Fillmore (1983), Chafe (1983), Crus (1990), Lehrer (1992), Kittay (1992), Pustejovsky (1993), Rey (1970), Talmy (1985), Winograd (1983) and others.

The peculiarities of polysemy are the major characteristics of the lexicalsemantic system of the language. This phenomenon, which is also called epidigmatics, represents a self-sufficient system of any language, since due to old words, by means of their rethinking, the lexicon extends, its semantic aspect becomes rich. It is known that the so-called original lexicon takes place in any language on the basis of which the whole lexical structure of the language is formed at a later stage. One of the ways, undoubtedly, is a word-formation by means of various word elements: prefixes, infixes, postfixes and so on, that is, word-formation formants. But 
not less important if not more, polysemy is a means of extending and developing the language lexical system, otherwise, the tropeization of original, direct meanings of words. It is the microsystems of polysemantic words where the cognitive status of semantic realizations of the word meaning variants is clearly manifested, that is, its lexical-semantic variant (LSV). "The peculiarities of polysemy generally determine the lexical specificity of the languages of the world and the discrepancy of their lexical structure" (Shmelev, 2006). The cognitive analysis of polysemy reveals what exact knowledge is reflected when extending the structure of polysemantic words, how they reflect knowledge about the world of a native speaker, and also provides a material for consideration about the mental and cultural characteristics of the nation the native speaker. So, Cubryakova (2004), speaking about the structure of a word meaning, uses the term "the cognitive map of a word". "It is possible to consider it (the cognitive map of a word) as a reflection of the most generally used contexts of a word... All together this provides insight into semantic networks connecting individual word meanings, and it is possible to speak about the cognitive structure as being frame-based". At the same time, the direct meaning of a word, according to Cubryakova (2004), is "a generating mechanism, a source of its various unfoldings", "a source and a starting point for new word usage". The works of Lakoff (1988), Chafe (1983), Shvedova (1984) are devoted to the so-called prototypical semantics, or generation of new meanings by the main meaning of a word.

It is necessary to speak about mental categories and not about concepts within the scope of the cognitive analysis of a polysemantic word: the microsystem's coverage of a polysemantic word not only of the conceptual sphere of the surrounding world, but also of the reflection in the lexical language system of such logical categories as repeatability, continuity of an action, infinity/finiteness of an action/state.

The volume of a word meaning with the identical direct meaning in one language never repeats its volume in another language. But there are still partial coincidences. How exactly does it happen? What is the range of semantic word realizations coinciding in their direct meanings in different languages? What is similar and what is different about the volumes of word meanings with identical meanings in different languages? The comparison of different languages in this respect gives an interesting material for observation and scientific interpretation. The study of this problem opens the veil of secrecy not only concerning the peculiarities of the structure and functioning of the lexical-semantic systems of human languages, but also allows to explain the peculiarities of a language cognition, that is, 1) to reveal the correlations between the structures of a language and the structures of knowledge, 2) to define the peculiarities of the specific language formations at the level of senses.

The cognitive-comparative method in this case even more emphasizes the specific character of the conceptual thinking of each nation, it more accurately represents the identity of linguistic thinking and conceptualization of the world, in our case, Russians and Englishmen. Our aim is to study, observe, reveal the range of figurative meanings of the English and Russian verbs coinciding in their direct meaning, to determine the specific and universal characteristics concerning polysemy in each language. This issue has been little studied (Kenetova, 2014).

As it is known, verbs can be dynamic and static (Maslov, 2000). In turn, there is a group of verbs of motion among dynamic verbs. "The Grammar of the Russian language" includes into the above group imperfective verbs denoting movement which are formed from one root and are grouped into binomial correlations, members of which are opposed in the meanings of multiplicity/nonmultiplicity, unidirectionality/non-unidirectionality. They are the following verbs: bezhat'-begat', an imperfective verb, but always with an additional lexical meaning which is introduced by a prefix: voyti, donesti, prignat', ukatit', poyti, ponesti,

XLinguae, Volume 10, Issue 4, October 2017, ISSN 1337-8384, eISSN 2453-711X 
pognat'. Secondary imperfective verbs are formed from the prefixal perfective verbs, thus an aspectual pair appears: privezti-privozit', privesti-privodit', prignat'prigonyat' and so on. Verbs of non-unidirectionality also form perfective verbs by adding the prefix: pobegat', ponosit', pokatat' and others. In this case, aspectual pairs are not formed (The Grammar of the Russian language, 1969).

Thus, the group of verbs of motion, including the prefixal formations from the given 14 pairs, is very extensive in the Russian language. Verbs of motion are presented differently in the English language. In the English grammar verbs of motion are not allocated into a separate category, as it is done in the Russian grammar. There are more verbs of motion in the English language than in Russian, as there are no categories of multiplicity/non-multiplicity, unidirectionality/non-unidirectionality in English. The category of repeating action and constant continued action is expressed by definite grammar constructions in it. So, two Russian non-prefixal imperfective verbs bezhat'-begat' and their derivatives (prefixal perfective verbs) correspond to one English verb to run, the Russian verbs vezti-vozit' correspond to 6 English verbs to convey, to carry, to take, to cart, to drive, to bring (Kenetova, 2014).

\section{Materials and Methods}

For our analysis we have taken the verbs of motion in the Russian and English languages which meanings are fixed in modern dictionaries: ekhat'-ezdit'/to go-to ride-to drive; idti-khodit'/to go-to walk- to come. The materials of the following dictionaries have been used in the article: "The English-Russian dictionary" by Prof. V.K. Muller (2007), "The Russian-English dictionary" (edited under O. S. Akhmanova). - M., 1969, and "Explanatory Dictionary of the Russian language" by S.I. Ozhegov and N. Shvedova (1999). During our analysis we used such linguistic methods as observation and description, the cognitive-comparative method.

As Gak (2010) notes, "the use of dictionary definitions of a lexical word meaning is one of the ways to study them" (Gak, 2010). Dictionaries offer linguistic material which includes conventional language units which is extremely important. We have not studied occasional and author's variants of word meanings. It should be also noted that the article deals with stylistically neutral lexicon. We do not touch upon the problem of stylistically colored verbs of motion.

The revealed semantic structures of the above verbs of motion are presented in the form of a table, at the same time, the method of semantic transfer is defined. "Two basic types of metaphor are distinguished: cognitive and figurative" (Dibrova, 1997). It is clear that poetic, figurative metaphors are beyond the scope of our study. As it has been already noted, the material of our research is the dictionary material, in which the cognitive figures of speech are fixed.

Table 1 illustrates the range of coincidence/discrepancy of Russian and English verbs in their value of meanings. 
Table 1: Semantics of the Russian verbs ekhat' - ezdit' and the English verbs to go, to ride, to drive

\begin{tabular}{|c|c|c|c|}
\hline Words & $\begin{array}{l}\text { Meaning of the words } \\
\text { ekhat }{ }^{\prime} \text { - ezdit' }\end{array}$ & $\begin{array}{l}\text { Meaning of the words } \\
\text { to go, to ride, to drive }\end{array}$ & $\begin{array}{c}\text { Types of } \\
\text { the word } \\
\text { meaning } \\
\text { transfer }\end{array}$ \\
\hline \multirow{16}{*}{$\begin{array}{l}\text { Rus. } \\
\text { ekhat' } \\
\text { Eng. } \\
\text { to go, to } \\
\text { ride, to } \\
\text { drive }\end{array}$} & $\begin{array}{l}\text { 1. To move, travel by land } \\
\text { or by water using any means } \\
\text { of transportation }\end{array}$ & $\begin{array}{l}\text { 1. To move from one } \\
\text { place to another; travel - } \\
\text { (to go, to ride, to drive) }\end{array}$ & direct \\
\hline & $\begin{array}{l}\text { 2. To move, to move } \\
\text { (vehicles) }\end{array}$ & $\begin{array}{l}\text { 2. To go, to ride, to } \\
\text { drive }\end{array}$ & metaphor \\
\hline & $\begin{array}{l}\text { 3. To move from the place, } \\
\text { to slip down, to slide }\end{array}$ & - & metaphor \\
\hline & - & To travel (to go) & metonymy \\
\hline & - & To leave, to start (to go) & metaphor \\
\hline & - & $\begin{array}{l}\text { To circulate, pass (to } \\
\text { go) - about money, } \\
\text { proverb }\end{array}$ & metaphor \\
\hline & - & $\begin{array}{l}\text { To go by bus, by tram } \\
\text { (to go) }\end{array}$ & metaphor \\
\hline & - & $\begin{array}{l}\text { To go by bike, by horse } \\
\text { (to ride) }\end{array}$ & metaphor \\
\hline & - & To ride on a back & metonymy \\
\hline & - & To sail, to glide (to go) & metaphor \\
\hline & - & To oppress (to ride) & metonymy \\
\hline & - & To nag (to ride) & metaphor \\
\hline & - & To tease, to rib (to ride) & metaphor \\
\hline & - & To drive a car & metaphor \\
\hline & - & $\begin{array}{l}\text { To move, to set in } \\
\text { motion (to drive) }\end{array}$ & metaphor \\
\hline & - & $\begin{array}{l}\text { To pave (the way, road) } \\
\text { - (to drive) }\end{array}$ & metaphor \\
\hline \multirow[t]{4}{*}{$\begin{array}{l}\text { Rus. } \\
\text { ezdit' } \\
\text { Eng. } \\
\text { to go, to } \\
\text { ride, to } \\
\text { drive }\end{array}$} & $\begin{array}{l}\text { 1. To move, travel by land } \\
\text { or by water using any means } \\
\text { of transportation } \\
\text { (repeatedly, at different } \\
\text { times and in different } \\
\text { directions, back and forth) } \\
\text { Constantly move(of vehicle) }\end{array}$ & $\begin{array}{l}\text { 1. To move from one } \\
\text { place to another; travel- } \\
\text { to go, to ride }\end{array}$ & direct \\
\hline & $\begin{array}{l}\text { 2. To go somewhere, to visit } \\
\text { somebody (using vehicles) }\end{array}$ & $\begin{array}{l}\text { 2. To travel, journey (by } \\
\text { land) }\end{array}$ & metonymy \\
\hline & $\begin{array}{l}\text { 3. To be able to use some } \\
\text { means of transportation }\end{array}$ & $\begin{array}{l}\text { 3. To drive (carriage, } \\
\text { car); to ride a bike } \\
\text { (cicle) }\end{array}$ & metonymy \\
\hline & $\begin{array}{l}\text { 4. To budge,slide, stray, not } \\
\text { being securely fastened to }\end{array}$ & - & metaphor \\
\hline
\end{tabular}


Table 2: Semantics of the Russian verbs idti - khodit' and the English verbs - to go, to walk, to come

\begin{tabular}{|c|c|c|c|}
\hline Words & $\begin{array}{c}\text { meaning of the words } \\
\text { idti - khodit' }\end{array}$ & $\begin{array}{l}\text { meaning of the words } \\
\text { to go, to walk, to come }\end{array}$ & $\begin{array}{l}\text { Types of } \\
\text { the word } \\
\text { meaning } \\
\text { transfer }\end{array}$ \\
\hline \multirow[t]{18}{*}{$\begin{array}{l}\text { Rus. } \\
\text { idti } \\
\text { Eng. } \\
\text { to go, } \\
\text { to walk, to } \\
\text { come }\end{array}$} & $\begin{array}{l}\text { 1. To move, stepping with } \\
\text { the feet }\end{array}$ & $\begin{array}{l}\text { 1. To move at a regular } \\
\text { pace by lifting and } \\
\text { setting down each foot } \\
\text { in turn, never having } \\
\text { both feet off the ground } \\
\text { at once (to go, to walk, } \\
\text { to come) }\end{array}$ & direct \\
\hline & $\begin{array}{l}\text { 2. To move, to move in } \\
\text { space or in time }\end{array}$ & $\begin{array}{l}\text { 2. To move, to move in } \\
\text { space or in time (to go) }\end{array}$ & metaphor \\
\hline & 3. To go anywhere & $\begin{array}{l}\text { 3. To go anywhere (to } \\
\text { go) }\end{array}$ & metonymy \\
\hline & $\begin{array}{l}\text { 4. To move somewhere to } \\
\text { achieve smth. }\end{array}$ & - & metonymy \\
\hline & $\begin{array}{l}\text { 5. To move after being } \\
\text { directed on purpose (only } \\
\text { for } 3 \text {-d person singular) }\end{array}$ & - & metaphor \\
\hline & $\begin{array}{l}\text { 6. To start doing smth., to } \\
\text { join smth., to become smb. }\end{array}$ & - & metaphor \\
\hline & $\begin{array}{l}\text { 7. To act like smb., to follow } \\
\text { smb. }\end{array}$ & - & metaphor \\
\hline & 8. To act in a way & - & metaphor \\
\hline & $\begin{array}{l}\text { 9. To approach, to appear, to } \\
\text { move (onto), to draw near; } \\
\text { to impend (only for } 3 \text {-d } \\
\text { person singular) }\end{array}$ & - & metaphor \\
\hline & $\begin{array}{l}\text { 10. To operate, to be in } \\
\text { action, run (mechanism, } \\
\text { machine) (only for } 3-\mathrm{d} \\
\text { person singular) }\end{array}$ & $\begin{array}{l}\text { 4. To operate, to be in } \\
\text { action, run (mechanism, } \\
\text { machine) (only for } 3-\mathrm{d} \\
\text { person singular) (to go) }\end{array}$ & metaphor \\
\hline & $\begin{array}{l}\text { 11. To fall, pouring } \\
\text { (rainfall) (only for } 3-\mathrm{d} \\
\text { person singular) }\end{array}$ & - & metaphor \\
\hline & $\begin{array}{l}\text { 12. To occur, to take place } \\
\text { (only for } 3 \text {-d person } \\
\text { singular) }\end{array}$ & - & metaphor \\
\hline & $\begin{array}{l}\text { 13. To perform, to be } \\
\text { staged (about the play) }\end{array}$ & - & metaphor \\
\hline & $\begin{array}{l}\text { 14. To pass, to stretch, to be } \\
\text { located }\end{array}$ & $\begin{array}{l}\text { 5. To pass, to stretch, to } \\
\text { be located (only for } 3-\mathrm{d} \\
\text { person singular) (to go) }\end{array}$ & metaphor \\
\hline & $\begin{array}{l}\text { 15. To come from, to } \\
\text { spread, to stand out }\end{array}$ & - & metaphor \\
\hline & $\begin{array}{l}\text { 16. To make a move in the } \\
\text { game }\end{array}$ & - & metaphor \\
\hline & 17. To succeed & - & metaphor \\
\hline & 18. To find a market, to be & - & metaphor \\
\hline
\end{tabular}




\begin{tabular}{|c|c|c|c|}
\hline & sold (colloquial) & & \\
\hline & $\begin{array}{l}\text { 19. To be due, payable, } \\
\text { issued }\end{array}$ & - & metaphor \\
\hline & $\begin{array}{l}\text { 20. To be intended, to be } \\
\text { used }\end{array}$ & - & metaphor \\
\hline & $\begin{array}{l}\text { 21. To correspond (to, with), } \\
\text { conform (to); be in keeping / } \\
\text { line (with), fit (only for 3-d } \\
\text { person singular) }\end{array}$ & - & metaphor \\
\hline & $\begin{array}{l}\text { 22. To enter; go in; come in; } \\
\text { go (into); come (into); log in }\end{array}$ & - & metaphor \\
\hline & $\begin{array}{l}\text { 23. To grow, to focus } \\
\text { growth on smth. }\end{array}$ & - & metaphor \\
\hline & $\begin{array}{l}\text { 24. To be ready for; to be } \\
\text { inclined to; to agree, to } \\
\text { decide on smth. }\end{array}$ & - & metaphor \\
\hline & $\begin{array}{l}\text { 25. To strive for a bait (fish, } \\
\text { animal) }\end{array}$ & - & metaphor \\
\hline & - & 6. To be driven (to go) & metaphor \\
\hline & - & $\begin{array}{l}\text { 7. To sound, to ring, to } \\
\text { beat (to go) }\end{array}$ & metaphor \\
\hline & - & $\begin{array}{l}\text { 8. To pass, to be } \\
\text { accepted (to go) }\end{array}$ & metaphor \\
\hline & - & $\begin{array}{l}\text { 9. To disappear, to } \\
\text { scatter (to go) }\end{array}$ & metaphor \\
\hline & - & 10. To die (to go) & metaphor \\
\hline & - & $\begin{array}{l}\text { 11. To pass into } \\
\text { ownership }\end{array}$ & metaphor \\
\hline & - & $\begin{array}{l}\text { 12. To walk, to go } \\
\text { around }\end{array}$ & metonymy \\
\hline & - & $\begin{array}{l}\text { 13. To walk a dog } \\
\text { [horse] }\end{array}$ & metonymy \\
\hline & - & $\begin{array}{l}\text { 14. To walk (about } \\
\text { ghost, spectre; spook) }\end{array}$ & metaphor \\
\hline $\begin{array}{l}\text { Rus. } \\
\text { khodit' } \\
\text { Eng. }\end{array}$ & $\begin{array}{l}\text { 1. Have the ability, to be } \\
\text { able to move, stepping with } \\
\text { the feet }\end{array}$ & $\begin{array}{l}\text { 1. Have the ability, to } \\
\text { be able to move from } \\
\text { one place to another by } \\
\text { feet (to walk, to go) }\end{array}$ & direct \\
\hline $\begin{array}{l}\text { to go, to } \\
\text { walk, come }\end{array}$ & $\begin{array}{l}\text { 2. To do the steps, crossing } \\
\text { in a different directions or at } \\
\text { different times }\end{array}$ & - & metonymy \\
\hline & $\begin{array}{l}\text { 3. To be going (to), head } \\
\text { (for), make (for), make one's } \\
\text { way (to, towards, into), } \\
\text { direct one's steps (to, } \\
\text { towards, into); pick one's } \\
\text { way (towards); wend one's } \\
\text { way (to) }\end{array}$ & $\begin{array}{l}\text { 2. To be going (to), } \\
\text { head (for), make (for), } \\
\text { make one's way (to, } \\
\text { towards, into), direct } \\
\text { one's steps (to, towards, } \\
\text { into); pick one's way } \\
\text { (towards); wend one's } \\
\text { way (to) (to go) }\end{array}$ & metonymy \\
\hline & $\begin{array}{l}\text { 4. To accompany, to follow, } \\
\text { to care for, to take care of }\end{array}$ & - & metonymy \\
\hline
\end{tabular}

XLinguae, Volume 10, Issue 4, October 2017, ISSN 1337-8384, eISSN 2453-711X 


\begin{tabular}{|l|l|l|l|}
\hline $\begin{array}{l}\text { 5. To wear smth., to look in } \\
\text { a way }\end{array}$ & - & metonymy \\
\hline 6. To be in a position, rank & - & metonymy \\
\hline $\begin{array}{l}\text { 7. To be in a condition, } \\
\text { mood }\end{array}$ & - & metonymy \\
\hline $\begin{array}{l}\text { 8. To make a move in the } \\
\text { game, to move a figure }\end{array}$ & - & metaphor \\
\hline $\begin{array}{l}\text { 9. To relieve natural needs } \\
\text { 10. To move any way by air } \\
\text { or by water, to sail (as a } \\
\text { member of the crew) }\end{array}$ & - & - & metonymy \\
\hline $\begin{array}{l}\text { 11. To move on a certain } \\
\text { root, in a certain direction } \\
\text { to go, to sail) }\end{array}$ & - & metaphor \\
\hline $\begin{array}{l}\text { 12. To move, to shift, to } \\
\text { travel }\end{array}$ & $\begin{array}{l}\text { 13. To move on(through) a } \\
\text { surface }\end{array}$ & - & metaphor \\
\hline $\begin{array}{l}\text { 14. To pass from one to } \\
\text { another, be in circulation }\end{array}$ & $\begin{array}{l}\text { 3. To pass from one to } \\
\text { another, be in } \\
\text { circulation (to go) }\end{array}$ & metaphor \\
\hline $\begin{array}{l}\text { 15. To spread, to cover (of } \\
\text { rumors, diseases) }\end{array}$ & $\begin{array}{l}\text { - } \\
\text { 16. To operate, to work (of } \\
\text { mechanisms) }\end{array}$ & $\begin{array}{l}\text { 4. To operate, to work } \\
\text { (of mechanisms) (to go) }\end{array}$ & metaphor \\
\hline $\begin{array}{l}\text { 17. To sway, to shake, to } \\
\text { tremble }\end{array}$ & metaphor \\
\hline
\end{tabular}

\section{Results and Discussion}

As we see from the material we have analyzed, the volume of meanings of Russian verbs ekhat-ezdit and English verbs to go-to ride-to drive does not correspond, which is not surprising since, as we have already mentioned, in the languages of the world the discrepancy in the volume of meanings of the words with the same sense is observed (in their direct meanings). Russian verbs ekhat-ezdit are contrasted on the grounds of multiplicity / nonmultiplicity, pointedness/ unpointedness. Nothing like this is observed in the English verbs, meaning "moving on any transport." There are three of them (to go-to ride-to drive) and they are not contrasted, rather they are synonymous. Each of the English verbs used in a particular context, has its own syntagmatic. Russian verbs ekhat-ezditl demonstrate the unity of common meaning "a movement in space on anything", but each of them has its own volume of meaning. The attribute of completeness/incompleteness of the action creates opportunities for various metaphorical and metonymical transference. The semantics of the verbs we analyze creates special difficulty in this matter. The Russian verb ezdit contains a sense of endless repetition of actions with definite purpose. This grammatical feature creates a huge potential for indirect meaning of the verb. There are no more complicated in its meaning words than the verbs of motion words, reflecting the ever-changing reality. Their meanings are elusive. This issue is complicated by the presence of a large number of prefixal verbs of perfect form in Russian language, which have no correspondence in the English grammatical system.

Three English verbs to go-to ride-to drive that correspond to Russian verbs ekhat- ezdit have 18 indirect meanings (see table. 1) The presence of such a large number of verbs with indirect meaning occurs due to the fact that we have not one, 
but three different verbs, and they are not themselves an indication of the repeatability/incompleteness of the action, as the Russian verbs are. The lack of this feature is compensated by the peculiarities of English grammar.

Russian verbs idti - khodit' contrasted on the ground of multiplicity / nonmultiplicity, pointedness / unpointedness of the action correspond to three English verbs to go-to walk-to come.

Russian verbs idti - khodit' have 41 indirect meaning, fixed as other analyzed words in the dictionary. English verbs to go-to walk-to come have 16 indirect meanings fixed in the dictionaries (see table 2). However, a large number of meanings fixed in Russian material are translated by entirely different words in the English language: such as pace, attend, tend, wear, lead, play, pass, run, and others.

\section{Conclusions}

What is the result of a small study which was carried out in terms of language cognition?

1. The logic of the language, especially the grammar, despite the fact that we analyzed the lexical material, shows uniqueness in each of the languages involved for analysis. The presence of perfect / imperfect form in Russian language and the absence of such an opposition in English once more confirms the long-ago established fact that the feaures of grammar are directly connected with its lexical system. We must not forget about the difference in the structure of Russian and English languages. The first has a vivid synthetic character, and the second is of an analytical structure. This difference also affects the choice of one or another way of transferring new indirect meanings. This phenomenon occurs not because of the knowledge of native speakers acquired in the process of their life, but because of the language intuition given them from birth, which can be also identified as a special knowledge / cognition.

2. Discrepancy of volume of word meanings denoting the same action, says about the difference in knowledge of Russian and English people in various ways. First of all, it is different associative thinking, different historical experience, landscape, geographic location. All this, of course, tells about the difference of structure of knowledge / cognition of these peoples, which is reflected in a certain way in the differences of the structure of their languages.

\section{Bibliographic references}

APRESYAN, Y.D. 1995. Selected papers. Moscow: Nauka. 472 p. ISBN 5-88766043-0, ISBN 5-02-017906-X.

CHEJF, U, 1983. Remembering and verbalization of past experience. In: Current Issues in foreign linguistics, vol. 7, pp. 35-73. ISSN 1387-6759.

CRUS, D.A. 1990. Prototype theory and lexical semantics. Meaning and prototypes. In: Studies in linguistic categorization, London. Rutledge. 578 p. ISBN: 9780415723732

DIBROVA, E.I. 1997. Modern Russian language. Moscow: Nauka. 77 p.

FILLMOR, C.H. 1983. Topics in lexical semantics. In: Current Issues in foreign linguistics, vol. 14, 23-60. ISSN 1387-6759.

FOMINA, M.I. 1990. Modern Russian language. Moscow: Nauka. 36 p.

GOLUBKOVA, O.N. - MASAliMOVA, A.R. - BIROVA, J. 2017. The Development of Sociocultural Competence in Future Translators Via the Methodology of Culture-Oriented Interpretation of English Language Fictional Texts. In: Man In India, vol. 97, n. 14, pp. 73-83. ISSN: 00251569.

GRAMMAR OF THE MODERN RUSSIAN LANGUAGE. 1970. Moscow: Nauka. pp. 345-346.

GAK, V.G. 2010. Comparative lexicology. Based on the French and Russian

XLinguae, Volume 10, Issue 4, October 2017, ISSN 1337-8384, eISSN 2453-711X 
languages. Moscow: Librocom. 264 p. ISBN: 978-5-397-01463-2.

KENETOVA, R.B. 2014. Verbs of motion in cognitive aspect. In: Izvestiya kabardino-balkarskogo nauchnogo tsentra RAN, vol. 6(62), 248-253. ISSN: 19916639

KUBRYAKOVA, E.S. 2004. Language and knowledge. Moscow. Nauka. 376 p.

LEHRER, A. - KITTAY, E.E. (Eds.) 1992. Frames, fields, and contrasts. New essays in semantic and lexical organization. Hillsdale: Lawrence Erlbaum. Lemmens, pp. 377-385.

LYONS, J. 1978. Introduction to theoretical linguistics. Moscow: Progress. 301 p.

LAKOFF, G. 1988. Thinking in the classifiers' mirror. In: Current Issues in foreign linguistics, vol. 23, pp.12-51. ISSN 1387-6759.

MULLER, V. K. 2007. English - russian dictionary. Moscow. Education. 888 p.

MASLOV, Y.S. 2000. Verb. In: Linguistic encyclopedic dictionary. Moscow. Education. 105 p.

OZHEGOV, S. I. - SHVEDOVA, N. YU. 1999. Explanatory dictionary of the Russian language. Moscow: Azbukovnik. 924 p.

PUSTEJOVSKY, J. 1993. Semantics and the lexicon. Dordrecht. Kluwer Academic Publishers. 284. ISSN: 9789401119726

REY, A. 1970. Lexicology Lectures. Paris: Klincksieck.

RUSSIAN-ENGLISH DICTIONARY (Eds. by O. S. Akhmanova). 1969. Moscow: Sovetskaya ehntsiklopediya. $562 \mathrm{p}$.

SENTENBERG, I.V. 1984. Lexical semantics of the English verb. Moscow: MSPI. $96 \mathrm{p}$.

SHMELEV, D.N. 2006. Modern Russian language. Vocabulary. Moscow: Prosveshhenie. 335 p.

SHVEDOVA, N.YU. 1984. About active potency embodied in the word. In: The word in grammar and in a dictionary. Moscow. pp. 7-15.

SOLNTSEV, V.M. 1971. Language as a systemic-structural formation. Moscow. Nauka. 222 p.

TALMY, L. 1985. Lexicalization patterns: Semantic structures in lexical forms. In: Language typology and syntactic description, vol. 3, pp. 57-149. ISSN 1430-0532

WINOGRAD, T. 1983. Language as a cognitive process. Cambridge. Cambridge University Press. 467 p. ISBN: 978-0521466073

ZHELTUKHINA, M.R. - SLYSHKIN, G.G. - MUZYKANT, V.L. PONOMARENKO, E.B. - MASALIMOVA, A.R. 2017a. Functional characteristics of the English and Russian media texts about the Sochi 2014 Winter Olympic Games: political and linguistic aspects. In: XLinguae, vol. 10, n. 3, pp. 83-100. ISSN 1337-8384.

ZHELTUKHINA, M.R. - VIKULOVA, L.G. - MIKHAYLOVA, S.V. BORBOTKO, L.A. - MASALIMOVA, A.R. 2017b. Communicative theatre space in the linguistic and pragmatic paradigm. In: XLinguae, vol. 10, n. 2, pp. 85-100. ISSN 1337-8384.

Words: 4000

Characters: 24693 (13,71 standard page)

Head of Foreign Languages Department Rita B. Kenetova, PhD

Kabardino-Balkarian State University

Chernishevskogo str. 173

Russia

ritakenetova@mail.ru 
Assoc. Prof. Alla V. Abregova, PhD

Foreign Languages Department

Kabardino-Balkarian State University

Chernishevskogo str. 173

360004 Nalchik

Russia

alla.abregova@yandex.ru

Assoc. Prof. Elmira R. Khutova, PhD

English Language Department

Kabardino-Balkarian State University

Chernishevskogo str. 173

360004 Nalchik

Russia

khutova@mail.ru

Assoc. Prof. Aminat G. Khamurzova, PhD

Romano-Germanic Languages Department

Kabardino-Balkarian State University

Chernishevskogo str. 173

360004 Nalchik

Russia

khamurzov99@mail.ru 